\title{
Biomass pretreatments capable of enabling lignin valorization in a biorefinery process
}

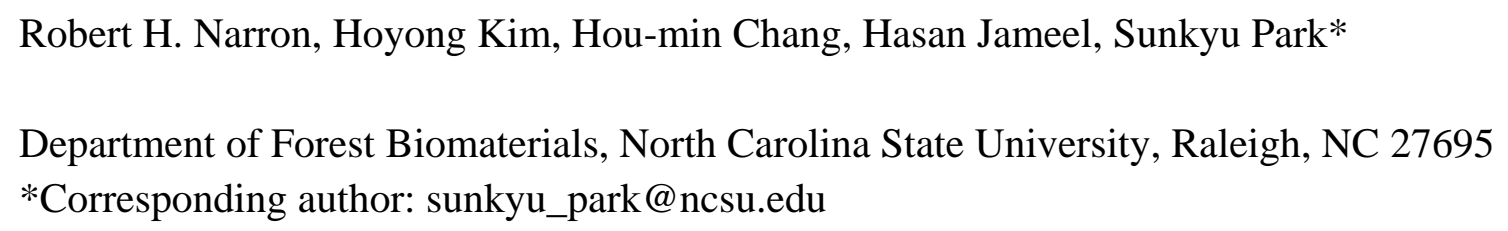

Recent techno-economic studies of proposed lignocellulosic biorefinery have concluded that creating value from lignin will assist realization of biomass utilization into valuable fuels, chemicals, and materials due to co-valorization and the new revenues beyond carbohydrates. The pretreatment step within a biorefinery process is essential for recovering carbohydrates, but different techniques and intensities have a variety of effects on lignin. Acidic and alkaline pretreatments have been shown to produce diverse lignins based on delignification chemistry. The valorization potential of pretreated lignin is affected by its chemical structure, which is known to degrade, with inter-lignin condensation under high-severity pretreatment. Covalorization of lignin and carbohydrates will require dampening of pretreatment intensities to avoid such effects, in spite of tradeoffs in carbohydrate production.

\section{Introduction}

To cultivate economic value from renewable biomass, pretreatment of incoming biomass is critical to overcome the recalcitrant properties of lignocellulosic biomass for downstream biological conversion. It is well known that lignin can inhibit both enzymatic saccharification and fermentation of carbohydrates, leading to the necessity of biomass pretreatment for lignin removal/disruption [1]. The diverse array of pretreatments that can be optimized for carbohydrate conversion have been reviewed in recent years [2-12]. In a newly published techno-economic analysis of a hypothetical industrial biorefinery, return on investment was highly susceptible to the incoming carbohydrate fraction in biomass [13]. In the best case, marginal returns were predicted in addition to addressing the market risks. These findings support the actively occurring paradigm shift in lignocellulosic biorefinery research towards valorization of the lignin fraction from biomass [14-26].

Despite recently successful investigations into novel methods of valorizing biorefinery lignin by conversion into precursors for different chemical and material applications, the published results remain at the laboratory scale [27-31]. In order to advance lignin-valorizing technologies, a comprehensive understanding of biorefinery lignin streams must be further established. Currently there exists a void of explicit knowledge regarding the modifications to lignin's properties after pretreatment across techniques. This dearth of knowledge leads to techno-economic models of industrial-scale biorefineries treating lignin solely as a power source for the biorefinery itself or as fuel pellets. With a better understanding of how lignin's structure is affected by pretreatment conditions, potential applications beyond combustion would be more 
readily innovated and developed. Furthermore, if any stream of biorefinery lignin can be valorized, then the profitability of the entire biorefinery would rise.

\section{Two lignin streams: hydrolyzate and residue}

The two potential streams from which lignin can be valorized within a biorefinery are pretreatment hydrolyzate (solubilized lignins) and post-saccharification residue (insoluble lignins). It is impossible to correlate the amount of lignin solubilized during pretreatment with valorization potential of soluble and insoluble lignins, due to inadequate data regarding the characteristics of the pretreated lignin. As shown in Table 1, when comparing diverse pretreatment processes and intensities across woody and non-woody biomasses, great variability in lignin solubilization is observed. Aside from percent delignification, there tends to be sparse discussion regarding the chemical properties of the lignin stream. This is mainly because current biorefinery research is focused on carbohydrate utilization with the absence of in-depth knowledge of whole lignin structure. Therefore it can be stated that current knowledge of lignin utilization is only in its fledgling state, marred by selective analysis that yields incomplete understanding of the entire lignin structure after pretreatment.

\section{Lignin properties for high-value applications}

Some of the potential applications for biorefinery lignin including Kraft lignin utilization [32-35] are under investigation in the area of carbon fibers for automobiles [36], hydrocarbons for transportation fuels and biochemicals [37], and petro-phenol substitution for resin adhesives [38]. For example, Domtar (Plymouth, NC, USA) opened the first industrial-scale LignoBoost ${ }^{\mathrm{TM}}$ operation for recovering Kraft lignin from black liquor in 2014. In order to evaluate applicability for lignin valorization, it is critical to define the characteristics of pretreated lignin that are sought for applications. Pretreated lignin can be considered to have greater valorization potential if the following criteria are met: 1) low degree of condensation, 2) chemically labile moieties for functionalization, and 3) low levels of impurity.

For lignin, the degree of condensation indicates the ratio of carbon-carbon bonds versus carbon-hydrogen and carbon-oxygen bonds. If the degree of condensation is high, then its application can be significantly affected due to the strength of the carbon-carbon bonds, which reduce lignin's potential for further modification. Also, it is known that increasing the degree of condensation will decrease enzymatic saccharification [39], leaving the residue with high amounts of carbohydrate impurities. The degree of condensation varies with different pretreatments depending upon pretreatment chemistry and intensity. However, the relationship between different pretreatments and the genesis of inter-lignin condensation is not yet understood. Concerning lignin's labile moieties for functionalization, targeted applications could potentially be developed if biorefinery lignin featured an appreciable amount of reactive moieties that can be functionalized for applications. The lignin biopolymer is formed through radical coupling between precursor monomers, yielding different chemically-bonded lignin in situ depending on the distributions of lignin monomeric precursors (para-hydroxyphenyl, guaiacyl, 
syringyl, or $\mathrm{H}, \mathrm{G}$ and $\mathrm{S}$, respectively). To have the residual lignin remain reactive and valorizable, it is ideal to maintain the native and labile alkyl-aryl ether bonds and not generate additional carbon-carbon linkages beyond those formed naturally during plant cell lignification. Regarding impurities, any stream of lignin in a biorefinery process will require an isolation process. The extent of association between lignin and any non-lignin components such as carbohydrates, silicates, and proteins, will drive the cost of producing lignin of adequate purity. Therefore any lignin stream that has inherently low impurity bears greater potential for valorization.

\section{Lignin from acidic pretreatment}

Due to the significant difference in lignin behavior spanning the aqueous $\mathrm{pH}$ range due to its ionizable phenol groups, pretreatments are classified by environmental $\mathrm{pH}$ in this review. Pretreatment using mineral acids (e.g. sulfuric [40] and nitric acid [41]) or organic acids (e.g. oxalic [42] and maleic acid [43]) continue to be investigated due to their ability to remove hemicellulose and lignin, which then enhances enzymatic hydrolysis. Concerning lignin in an acidic medium, the driving force for chemical reactivity begins with hydronium protonation of a hydroxyl functional group which exists in chemical equilibrium with a reactive carbocation. The acidolysis of lignin's alkyl-aryl ethers has been recently revisited using lignin dimer model compounds and was successful in elucidating the reaction routes for non-phenolic $\beta-\mathrm{O}-4$ ' ethers in acidic media, Figure 1 [44]. Acidolysis is considered to be one of the major reaction pathways for lignin during acidic pretreatment, cleaving $\beta-\mathrm{O}-4$ ' ethers to generate either a $\beta$-ketone (Hibbert's ketone) or an aldehyde functionality on one lignin molecule and liberating a free phenol functionality on another [45]. However, in addition to acidolysis, low pH can promote undesired inter-lignin condensation reactions (Route 4), which decreases lignin's valorization potential and result in saccharification inhibition [46]. Inter-lignin condensation occurs when the carbocation does not proceed with acidolysis but rather participates in electrophilic aromatic substitution involving another aromatic proton. In this regard, autohydrolysis pretreatment, which generates weak acetic acids by cleavage of acetyl groups in hemicellulose, presents a unique opportunity that can reduce lignin reaction in acidic environments [47].

Recent examples highlight the strengths and weakness of acidic pretreatment schemes. By using sequential autohydrolysis and ethanol organosolv pretreatment to generate two streams-carbohydrates and high-purity lignin [48]-a remarkable $68.7 \%$ yield of high-purity lignin was achieved with $89.3 \%$ carbohydrate yield from enzymatic hydrolysis. The amount of condensed $\mathrm{G}$ and $\mathrm{S}$ moieties bearing hydroxyl functionalities in the dually-pretreated lignin did increase compared to lignin from the raw material (0.07 to $0.96 \mathrm{mmol} / \mathrm{g}$ lignin). However, a greater increase in the same moieties from non-condensed $G$ and $S$ was also observed $(0.62$ to $2.16 \mathrm{mmol} / \mathrm{g}$ lignin). It was found that the entirety of the original $\beta-\mathrm{O}-4$ ' and $\beta-5$ ' substructures had been disrupted, leaving mainly native $\beta-\beta$ ' substructures in the lignin. Thus, the amount of non-condensed structures more than doubled. An alternative pretreatment process, involving pure water under a pressurized oxygenated atmosphere followed by rapid explosion, was 
recently used in a significant discovery involving the chemical structure of lignin [49]. Pretreatment of loblolly pine using this process, was found to increase the methoxy content in lignin by conversion of $\mathrm{H}$ moieties into $\mathrm{S}$ moieties by oxygen. This finding sheds light on a new chemical mechanism of lignin transformation during pretreatment, which renders a less condensable and thus possibly more-valorizable residual lignin stream.

\section{Lignin from alkaline pretreatment}

Pretreatment with alkaline chemicals (e.g. sodium hydroxide [40] and ammonia [50]) is also under investigation due to the established alkaline delignification chemistry from the pulping industry. Large quantities of lignin are dissolved into alkaline solution creating an alkaline hydrolyzate. Under the conditions of alkaline pretreatment, nucleophilic cleavage of lignin's phenolic alkyl-aryl ethers occurs, promoting lignin solvation into alkali. These reaction pathways are summarized in Figure 2. Concerning alkaline pretreatment chemistry, non-phenolic alkyl-aryl ether cleavage was studied recently using lignin dimer model compounds with and without a $\gamma$-carbon hydroxyl group, concluding that the presence of this hydroxyl group results in steric hindrance towards bond scission of $\mathrm{S}$ lignin as the second aromatic ring [51]. The initially-high $\mathrm{pH}$ continuously decreases as neutralizing compounds from the biomass are solubilized during pretreatment; for example, acetic acid, sugar acids (iso-, meta-saccharinic acid), and new phenol groups on lignin. The $\mathrm{pH}$ of the hydrolyzate affects the degree of lignin solubility, consequently pretreatment vessels with metered alkali input are required for delignification optimization. However, excessive alkaline conditions with respect to the chosen nucleophile's pKa will promote nucleophilicity, fostering inter-lignin condensation (Route 4). In the case of Kraft pulping, sulfur-corrupted and highly condensed Kraft lignin solvated in hydrolyzate (i.e. black liquor) is produced, which is combusted for the purpose of alkaline chemical recovery and steam/power production.

It terms of the amount of lignin solubilized in hydrolyzate, it was found that twice the soda charge was required to achieve identical delignification (72\%) of switchgrass compared to corn stover [52], indicating that the lignin in saccharification residues can contain significant carbohydrate impurities depending upon the digestibility of the pretreated solids. The watersoluble components from AFEX (ammonia fiber explosion) pretreated material was analyzed in terms of molecular weight and fractionated $(<3 \mathrm{kDa}, 3-10 \mathrm{kDa}$, and $>10 \mathrm{kDa})$ [53] and it was concluded that the $<3 \mathrm{kDa}$ fraction inhibited enzymatic hydrolysis the most. Of this fraction, it was found that up to $25 \%$ consisted of oligomeric hemicelluloses linked either covalently or noncovalently. Alkaline hydrolyzates have also been studied for differences in solubilized lignin molecular weight for downstream valorization [54]. Dissolved pine lignin was observed to have a higher molecular weight compared to birch $(\sim 5.5 \mathrm{kDa}$ vs. $\sim 4 \mathrm{kDa})$, yet with the best delignification only $15 \%$ of the softwood and $16 \%$ of the hardwood lignin was solubilized. Through combination of sequential ionic liquid and alkali pretreatment, up to $36 \%$ delignification of Eucalyptus was reported, but more significantly, the lignin in the saccharification residue was found to be highly similar to lignin in situ, with $77 \%$ and $20 \%$ of all 
1 lignin side chains being native $\beta-\mathrm{O}-4$ ' and $\beta-\beta$ ' substructures, respectively [55]. This indicates

2 that ionic liquid and alkaline pretreatment could render valorizable lignin in the saccharification 3 residue due to its well-preserved structure. However, the high cost of ionic liquides might 4 reduce their industrial applicability. Using hot deionized water $\left(140{ }^{\circ} \mathrm{C}\right)$ with $1 \% \mathrm{NaOH}, 81 \%$ 5 delignification of rice straw was reported [56] with the residual solid lignin retaining some of its 6 original $\beta$-O-4' substructures due to the retardation effect from hydroxide ions on alkyl-aryl ether 7 acidolysis reactions [57]. In a study of pretreatment effects on the lignin structure of olive tree 8 prunings [58], solvent-extracted solid lignin after alkaline pretreatment $\left(7.5 \% \mathrm{NaOH}\right.$ at $90^{\circ} \mathrm{C} / 90$ $9 \mathrm{~min}$ ) was found to contain high amounts of impurities and the extracted lignin was mainly 10 composed of $\mathrm{G}$ lignin ( $\mathrm{S} / \mathrm{G}$ ratio of 0.75 ) with two times higher molecular weight compared to 11 the lignin obtained from hydrothermal pretreatment. These findings show a low-yield and highly 12 impure lignin with condensable $\mathrm{G}$ moieties is generated from alkaline pretreatment of this 13 agricultural waste.

\section{Closing Remarks}

Figure 3 presents a graphical representation of where established pretreatment technologies exist with respect to valorization of carbohydrates along the lines of pretreatment $\mathrm{pH}$ and intensity. Optimal pretreatment conditions for carbohydrate production exist, but optimal pretreatments for co-valorization of both carbohydrates and lignins remain to be identified. By establishing which pretreatments can be used to valorize lignin, it will then become possible to investigate an optimum window in which a biorefinery can pretreat incoming biomass to enable simultaneous valorization of carbohydrates and lignins. If pretreatments are optimized from the lens of co-valorization with decreased severities and milder $\mathrm{pH}$ 's, then the economic prospects of the lignocellulosic biorefinery process will increase, as will the likelihood 25 of industrial investment in such an operation.

\section{Acknowledgments}

28 This work is supported by USDA NIFA's National Needs Foundation (no. 2013-38420-20522)

29 and Agriculture and Food Research Initiative Competitive Grant (IBSS project, no. 2011-6800530 30410). 
1 Table 1. Summary of pretreatments, severities, delignification, and impacts on lignin structure

\begin{tabular}{|c|c|c|c|c|c|c|}
\hline \multirow[t]{2}{*}{ Pretreatment } & Conditions & $\mathrm{pH}$ & Biomass & $\mathrm{Wt} \%$ & Impact on & Ref. \\
\hline & \multicolumn{6}{|c|}{ Delignification lignin structure } \\
\hline Dilute acid & $130{ }^{\circ} \mathrm{C}, 60 \mathrm{~min}$ & Acidic & Rape straw & $42 \%$ & - & [59] \\
\hline \multirow[t]{3}{*}{ (Sulfuric acid) } & $30^{\circ} \mathrm{C}, \quad 7 \mathrm{~h}$ & Acidic & Banana peel & $38 \%$ & - & {$[60]$} \\
\hline & $190^{\circ} \mathrm{C}, \quad 1 \mathrm{~min}$ & Acidic & Switchgrass & $0 \%$ & $\begin{array}{l}\mathrm{C} \beta \text { in } \beta-\mathrm{O}-4, \mathrm{C} \alpha \text { in } \beta-5 \text { and } \beta-\beta \\
0.74 \text { (untreated); } 0.54 \text { (pretreated) } \\
\mathrm{C} \gamma \text { in } \beta-5 \text { and } \beta-\mathrm{O}-4 \text { with } \mathrm{C} \alpha=\mathrm{O} \text { in } \mathrm{G} \text { and } \mathrm{S} \text { units } \\
0.35 \text { (untreated); } 0.20 \text { (pretreated) } \\
\mathrm{C} \gamma \text { in } \beta-\mathrm{O}-4 \text { without } \mathrm{C} \alpha=\mathrm{O} \\
0.39 \text { (untreated); } 0.25 \text { (pretreated) }\end{array}$ & {$[61]$} \\
\hline & $100 \sim 190{ }^{\circ} \mathrm{C}, 2 \mathrm{~h}$ & Acidic & Poplar & - & $\begin{array}{l}\text { Nitrobenzene oxidation products } \\
\text { Vanillin } 53.3 \% \text {, Syringaldehyde } 22.0 \%\left(100^{\circ} \mathrm{C}\right) \\
\text { Vanillin } 41.9 \% \text {, Syringaldehyde } 16.8 \%\left(170^{\circ} \mathrm{C}\right) \\
\text { Vanillin } 17.8 \% \text {, Syringaldehyde } 12.6 \%\left(190^{\circ} \mathrm{C}\right)\end{array}$ & {$[62]$} \\
\hline Steam & $170{ }^{\circ} \mathrm{C}, \quad 3 \mathrm{~min}$ & Acidic & Wheat straw & $64 \%$ & - & {$[63]$} \\
\hline \multirow[t]{3}{*}{ explosion } & $185^{\circ} \mathrm{C}, \quad 5 \mathrm{~min}$ & Acidic & Aspen & $10 \%$ & $\begin{array}{l}\text { Total } \beta-\mathrm{O}-4 \\
54 / 100 \mathrm{Ar} \text { (untreated) } \\
42 / 100 \mathrm{Ar} \text { (pretreated) }\end{array}$ & {$[64]$} \\
\hline & $200^{\circ} \mathrm{C}, 15 \mathrm{~min}$ & Acidic & Aspen & $20 \%$ & 18/100 Ar (pretreated) & \\
\hline & $180^{\circ} \mathrm{C}, 10 \mathrm{~min}$ & Acidic & $\begin{array}{l}\text { Sugarcane } \\
\text { bagasse }\end{array}$ & $9 \%$ & $\begin{array}{l}\text { Total } \beta-\mathrm{O}-4 \\
\text { 25.3-31.7/100 Ar (untreated) } \\
\text { 16.7-20.7/100 Ar (pretreated) }\end{array}$ & {$[65]$} \\
\hline \multirow[t]{3}{*}{ Autohydrolysis } & $177^{\circ} \mathrm{C}, \quad 3.5 \mathrm{~h}$ & Acidic & Aspen & $62 \%$ & $\begin{array}{l}\text { Total } \beta-\mathrm{O}-4 \\
54 / 100 \mathrm{Ar} \text { (untreated) } \\
34 / 100 \mathrm{Ar} \text { (pretreated) }\end{array}$ & [57] \\
\hline & $195^{\circ} \mathrm{C}, \quad 6 \mathrm{~min}$ & Acidic & Wheat straw & $42 \%$ & - & {$[63]$} \\
\hline & $180^{\circ} \mathrm{C}, 15 \mathrm{~min}$ & Acidic & $\begin{array}{l}\text { Eucalyptus } \\
\text { alkali lignin }\end{array}$ & $26 \%$ & $\begin{array}{l}\text { Total } \beta-\mathrm{O}-4 \\
\text { 61.2/100 Ar (untreated) } \\
\text { 30.8/100 Ar (pretreated) }\end{array}$ & {$[66]$} \\
\hline \multirow{5}{*}{$\begin{array}{l}\text { Organosolv } \\
\text { (Methyl isobutyl } \\
\text { ketone, Ethanol, } \\
\text { Water, Sulfuric } \\
\text { acid) }\end{array}$} & $140{ }^{\circ} \mathrm{C}, 56 \mathrm{~min}$ & Acidic & $\begin{array}{l}\text { Mixed } \\
\text { hardwoods }\end{array}$ & $97 \%$ & - & [67] \\
\hline & $160^{\circ} \mathrm{C}, 56 \mathrm{~min}$ & Acidic & $\begin{array}{l}\text { Mixed } \\
\text { hardwoods }\end{array}$ & $98 \%$ & - & [67] \\
\hline & $140{ }^{\circ} \mathrm{C}, 56 \mathrm{~min}$ & Acidic & Switchgrass & $64 \%$ & $\begin{array}{l}\text { Total } \beta-\mathrm{O}-4 \\
\text { 37/100 Ar (untreated) } \\
\text { 17/100 Ar (organosolv lignin) }\end{array}$ & {$[68]$} \\
\hline & $160{ }^{\circ} \mathrm{C}, 56 \mathrm{~min}$ & Acidic & Switchgrass & $73 \%$ & 4/100 Ar (organosolv lignin) & {$[68]$} \\
\hline & $190^{\circ} \mathrm{C}, 1 \mathrm{~h}$ & Acidic & Switchgrass & $61 \%$ & $\begin{array}{l}\text { Total phenolic } \mathrm{OH} \\
0.86 \mathrm{mmol} / \mathrm{g} \text { of lignin (untreated) } \\
1.90 \mathrm{mmol} / \mathrm{g} \text { of lignin (organosolv treated) } \\
1.65 \mathrm{mmol} / \mathrm{g} \text { of lignin (organosolv lignin) }\end{array}$ & [69] \\
\hline Alkaline green & $160^{\circ} \mathrm{C}, 60 \mathrm{~min}$ & Alkaline & Poplar & $18 \%$ & - & {$[70]$} \\
\hline \multirow{2}{*}{$\begin{array}{l}\text { liquor (Sodium } \\
\text { sulfide \& Sodium } \\
\text { carbonate) }\end{array}$} & $140^{\circ} \mathrm{C}, 60 \mathrm{~min}$ & Alkaline & Miscanthus & $54 \%$ & - & {$[70]$} \\
\hline & $170^{\circ} \mathrm{C}, 3 \mathrm{~h}$ & Alkaline & $\begin{array}{l}\text { Oil palm } \\
\text { frond }\end{array}$ & - & $\begin{array}{l}\text { Nitrobenzene oxidation products } \\
\text { Vanillin } 0.5 \% \text {, Syringaldehyde } 0.7 \% \text { (Kraft) } \\
\text { Vanillin } 0.7 \% \text {, Syringaldehyde } 1.5 \% \text { (Soda) }\end{array}$ & [71] \\
\hline
\end{tabular}


$190^{\circ} \mathrm{C}, 1 \mathrm{~h} \quad$ Alkaline

Vanillin 1.6\%, Syringaldehyde 4.6\% (Organosolv)

Mild alkaline

$175^{\circ} \mathrm{C}, 15 \mathrm{~min}$

(Sodium

$175^{\circ} \mathrm{C}, 15 \mathrm{~min}$

Alkaline Eucalyptus

$36 \%$

hydroxide; $15 \%$

Alkaline Sugarcane $80 \%$

soda charge)

Ionic liquid and $110^{\circ} \mathrm{C}, 12 \mathrm{~h}$

bagasse

$-$

alkaline

$75^{\circ} \mathrm{C}, \quad 3 \mathrm{~h}$

Poplar

Relative abundance of $\beta-\mathrm{O}-4$

[73]

Ionic liquid

$110^{\circ} \mathrm{C}, 12 \mathrm{~h}$

Birch

$26 \%$

$79.0 \%$ (untreated); $80.2 \%$ (pretreated)

65/100 Ar (cellulolytic lignin)

56/100 Ar (ionic liquid lignin)

59/100 Ar (residual lignin)

1

2

3

4

5

6

7

8

9

10

11

12

13
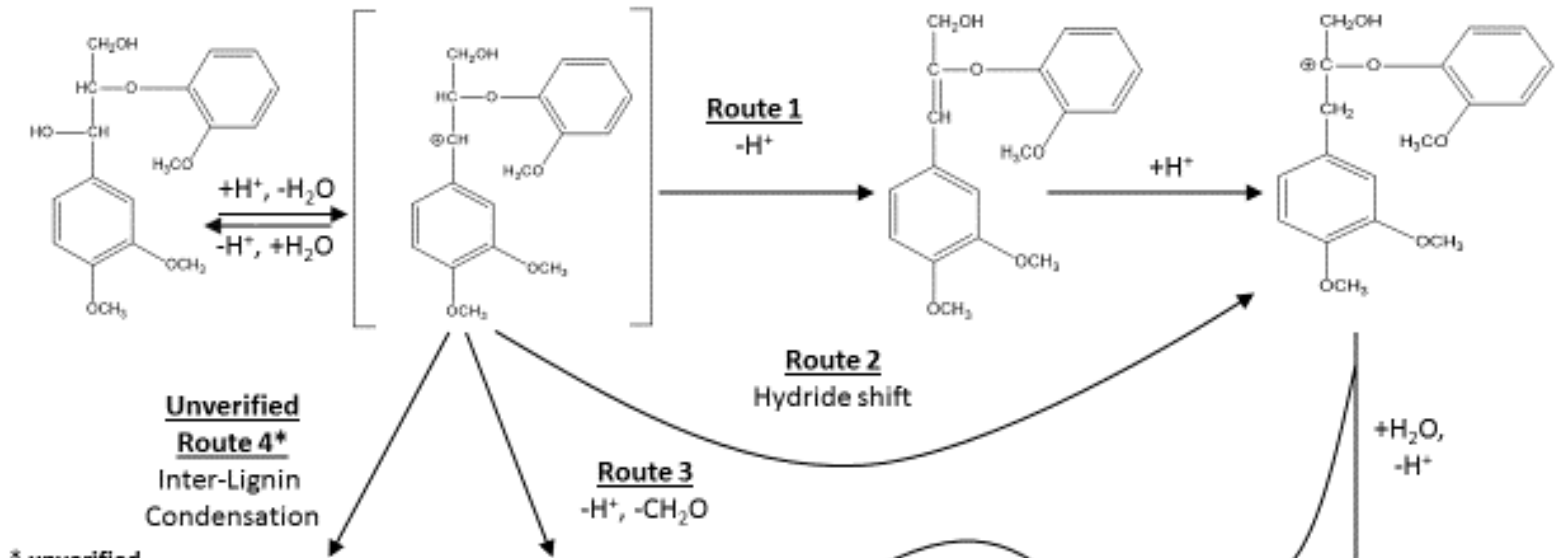

* unverified
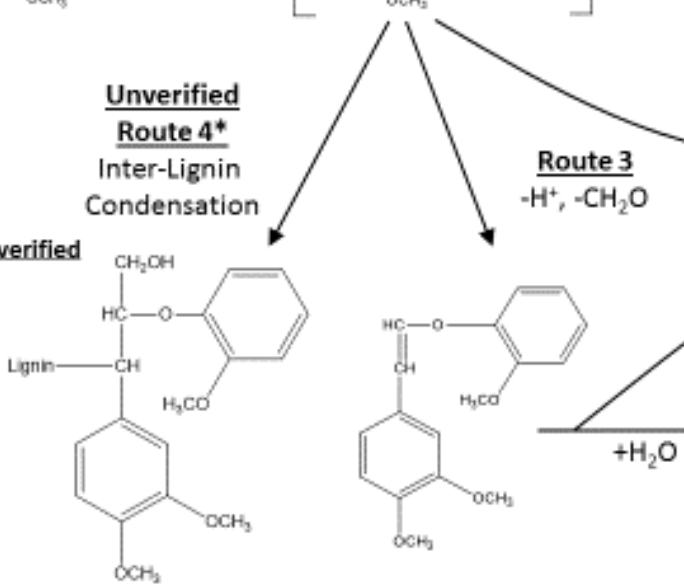

Route 2

Hydride shift
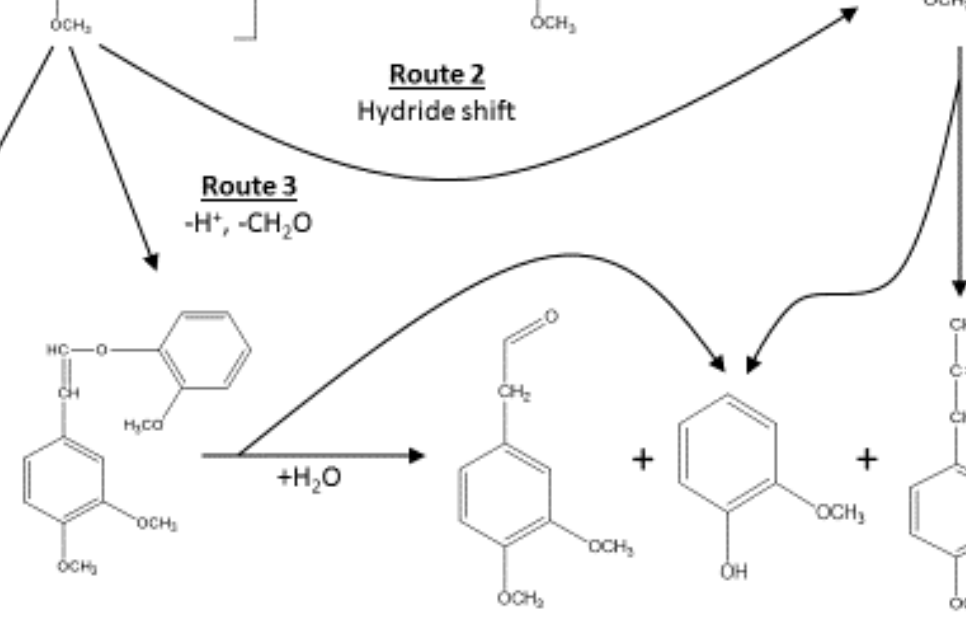

$+\mathrm{H}_{2} \mathrm{O}$

Figure 1. Acidolysis reaction pathways of model non-phenolic $\beta-\mathrm{O}-4$ ' lignin dimers

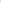


<smiles>OCCOc1ccc(C(O)C(O)CO)cc1O</smiles><smiles>CCCO</smiles>

Route 1 Inter-Lignin Condensation<smiles>COc1cc(C(C)(C)c2ccc([O-])c(OC)c2)ccc1[O-]</smiles><smiles>CC(O)=CC(C)O</smiles>
$\frac{\text { Route } 1}{-\mathrm{CH}_{2} \mathrm{O}}$
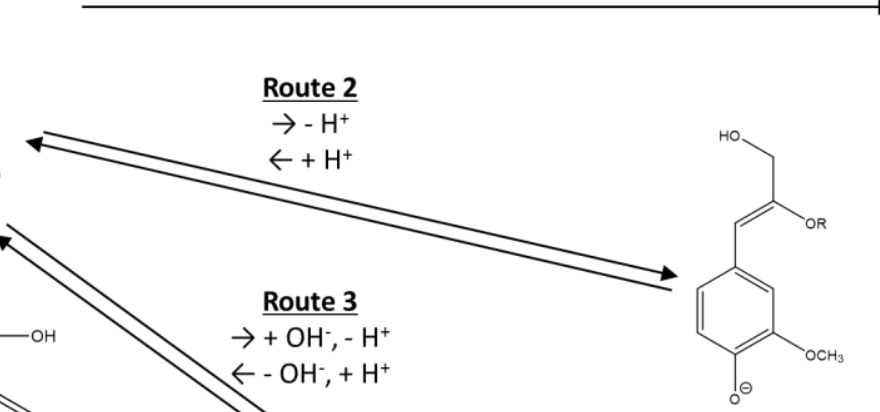

$\rightarrow+\mathrm{OH}^{-},-\mathrm{H}^{+}$

$\leftarrow-\mathrm{OH}^{-},+\mathrm{H}^{+}$
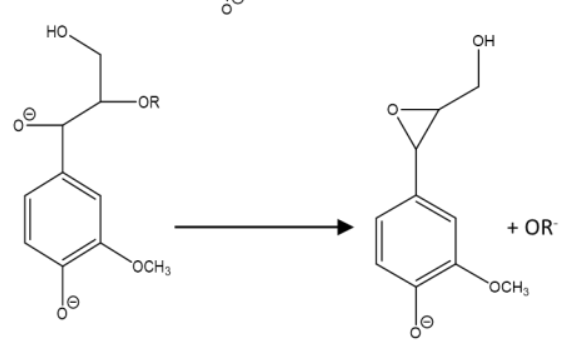

Figure 2. Hydroxide ion cleavage reaction pathways of phenolic $\beta$-O-4' lignin structures

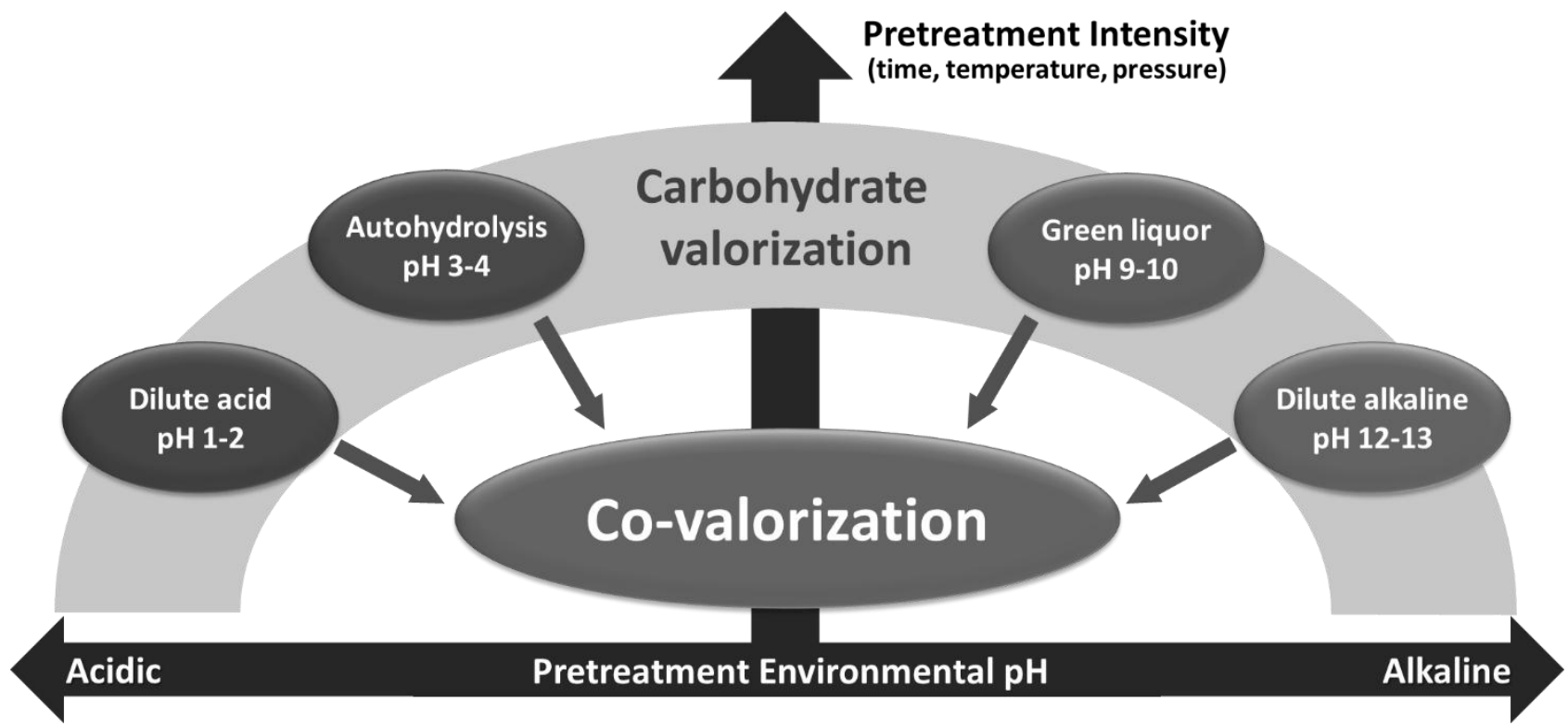

8 Figure 3. Pretreatment $\mathrm{pH}$ and intensities versus valorized fractions of lignocellulosic biomass 9 


\section{References and Recommended Reading}

$1 \bullet$. Zeng Y, Zhao S, Yang S, Ding S-Y: Lignin plays a negative role in the biochemical process for producing lignocellulosic biofuels. Curr Opin Biotechnol 2014, 27:38-45.

The authors clearly explain the negative impacts of lignin on the biological transformation of carbohydrates and potential methods for overcoming these negative impacts.

2. Barakat $A$, de Vries $H$, Rouau $X$ : Dry fractionation process as an important step in current and future lignocellulose biorefineries: a review. Bioresour Technol 2013, 134:362-373.

3. Bhagwat S, Ratnaparkhe S, Kumar A: Biomass Pre-treatment Methods and Their Economic Viability for Efficient Production of Biofuel. Br Biotechnol J 2015, 8:1-17.

4. Brodeur G, Yau E, Badal K, Collier J, Ramachandran K, Ramakrishnan S: Chemical and physicochemical pretreatment of lignocellulosic biomass: a review. Enzyme Res 2011, 2011:1-17.

5. Davis R, Tao L, Scarlata C, Tan E, Ross J, Lukas J, Sexton D: Process Design and Economics for the Conversion of Lignocellulosic Biomass to Hydrocarbons: Dilute-Acid and Enzymatic Deconstruction of Biomass to Sugars and Catalytic Conversion of Sugars to Hydrocarbons. National Renewable Energy Laboratory, Golden, CO; 2015.

6. Humbird D, Davis R, Tao L, Kinchin C, Hsu D, Aden A, Schoen P, Lukas J, Olthof B, Worley M: Process design and economics for biochemical conversion of lignocellulosic biomass to ethanol: dilute-acid pretreatment and enzymatic hydrolysis of corn stover. National Renewable Energy Laboratory, Golden, CO; 2011.

7. Khoo HH: Review of bio-conversion pathways of lignocellulose-to-ethanol: Sustainability assessment based on land footprint projections. Renew Sust Energ Rev 2015, 46:100-119.

8. Sathitsuksanoh N, George A, Zhang Y, Percival H: New lignocellulose pretreatments using cellulose solvents: a review. J Chem Technol Biotechnol 2013, 88:169-180.

9. Shi J, George KW, Sun N, He W, Li C, Stavila V, Keasling JD, Simmons BA, Lee TS, Singh S: Impact of Pretreatment Technologies on Saccharification and Isopentenol Fermentation of Mixed Lignocellulosic Feedstocks. BioEnergy Res 2015, 8:1004-1013.

10. Singh J, Suhag M, Dhaka A: Augmented digestion of lignocellulose by steam explosion, acid and alkaline pretreatment methods: a review. Carbohydr Polym 2015, 117:624-631.

11. van der Pol EC, Bakker RR, Baets $P$, Eggink $G$ : By-products resulting from lignocellulose pretreatment and their inhibitory effect on fermentations for (bio) chemicals and fuels. Appl Microbiol Biotechnol 2014, 98:9579-9593.

12. Xu Z, Huang F: Pretreatment methods for bioethanol production. Appl Biochem Biotechnol 2014, 174:43-62.

13••. Treasure T, Gonzalez R, Jameel H, Phillips RB, Park S, Kelley S: Integrated conversion, financial, and risk modeling of cellulosic ethanol from woody and non- woody biomass via dilute acid pre- treatment. Biofuels, Bioprod Biorefin 2014, 8:755-769.

Six feedstocks were evaluated with financial simulations of a potential bioethanol biorefinery project. Probabilities of $12 \%$ internal rate of returns were highly dependent upon raw feedstock carbohydrate composition.

14. Zamudio MA, Alfaro A, de Alva HE, García JC, García-Morales M, López F: Biorefinery of paulownia by autohydrolysis and soda- anthraquinone delignification process. Characterization and application of lignin. J Chem Technol Biotechnol 2015, 90:534-542.

15. Li H, Sivasankarapillai G, McDonald AG: Lignin valorization by forming toughened thermally stimulated shape memory copolymeric elastomers: Evaluation of different fractionated industrial lignins. J Appl Polym Sci 2015, 132:1-12.

16. Albarelli JQ, Mian A, Santos DT, Ensinas AV, Maréchal F, Meireles MAA: Valorization of sugarcane biorefinery residues using supercritical water gasification: A case study and perspectives. $J$ Supercrit Fluids 2015, 96:133-143.

17. Santos JI, Martín-Sampedro R, Fillat Ú, Oliva JM, Negro MJ, Ballesteros M, Eugenio ME, Ibarra D: Evaluating Lignin-Rich Residues from Biochemical Ethanol Production of Wheat Straw and Olive Tree Pruning by FTIR and 2D-NMR. Int J Polym Sci 2015, 2015:1-11. 
18. Espinoza Acosta JL, Torres Chávez PI, Ramírez-Wong B, Bello-Pérez LA, Vega Ríos A, Carvajal Millán E, Plascencia Jatomea M, Ledesma Osuna Al: Mechanical, thermal, and antioxidant properties of composite films prepared from durum wheat starch and lignin. Starch - Stärke 2015, 67:502-511.

19. Ten E, Vermerris W: Recent developments in polymers derived from industrial lignin. J Appl Polym Sci 2015, 132:1-13.

20. Hu L, Stevanovic T, Rodrigue D: Comparative Study of Polyethylene Composites Containing Industrial Lignins. Polym Polym Compos 2015, 23:369.

21. Xie J, Hse CY, Shupe TF, Hu T: Physicochemical characterization of lignin recovered from microwave- assisted delignified lignocellulosic biomass for use in biobased materials. J Appl Polym Sci 2015, 132:1-7.

22. Ma R, Xu Y, Zhang X: Catalytic Oxidation of Biorefinery Lignin to Value- added Chemicals to Support Sustainable Biofuel Production. ChemSusChem 2015, 8:24-51.

23. Leskinen T, Kelley SS, Argyropoulos DS: Refining of ethanol biorefinery residues to isolate value added lignins. ACS Sustain Chem Eng 2015, 3:1632-1641.

The authors report investigations of processes for upgrading residual biorefinery lignin using solvent extraction. Lignin yields from the residue could be increased using acid or alkaline chemicals but doing so changed the lignin functional groups, molecular weight and thermal properties.

24. Rahimi A, Ulbrich A, Coon JJ, Stahl SS: Formic-acid-induced depolymerization of oxidized lignin to aromatics. Nature 2014, 515:249-252.

25. Öhrman OG, Weiland F, Pettersson E, Johansson A-C, Hedman H, Pedersen M: Pressurized oxygen blown entrained flow gasification of a biorefinery lignin residue. Fuel Process Technol 2013, 115:130-138.

26. Zhang W, Ma Y, Wang C, Li S, Zhang M, Chu F: Preparation and properties of lignin-phenol-formaldehyde resins based on different biorefinery residues of agricultural biomass. Ind Crop Prod 2013, 43:326333.

27. Deepa AK, Dhepe PL: Lignin Depolymerization into Aromatic Monomers over Solid Acid Catalysts. ACS Catal 2015, 5:365-379.

28. Krutov SM, Evtuguin DV, Ipatova EV, Santos SAO, Sazanov YN: Modification of acid hydrolysis lignin for value-added applications by micronization followed by hydrothermal alkaline treatment. Holzforschung 2015, 69:761-768.

29. Ma R, Hao W, Ma X, Tian Y, Li Y: Catalytic Ethanolysis of Kraft Lignin into High-Value Small-Molecular Chemicals over a Nanostructured a-Molybdenum Carbide Catalyst. Angew Chem Int Ed Engl 2014, 126:7438-7443.

30. Singh SK, Ekhe JD: Towards effective lignin conversion: HZSM-5 catalyzed one-pot solvolytic depolymerization/hydrodeoxygenation of lignin into value added compounds. RSC Advances 2014, 4:27971-27978.

31. Zeng J, Yoo CG, Wang F, Pan X, Vermerris W, Tong Z: Biomimetic Fenton-Catalyzed Lignin Depolymerization to High-Value Aromatics and Dicarboxylic Acids. ChemSusChem 2015, 8:861-871.

32. Ma X, Cui K, Hao W, Ma R, Tian Y, Li Y: Alumina supported molybdenum catalyst for lignin valorization: Effect of reduction temperature. Bioresour Technol 2015, 192:17-22.

33. Awungacha Lekelefac C, Busse N, Herrenbauer M, Czermak P: Photocatalytic based degradation processes of lignin derivatives. Int $J$ Photoenergy 2014, 2015:1-18.

34. Zhou XF: Catalytic oxidation and conversion of kraft lignin into phenolic products using zeolite- encapsulated $\mathrm{Cu}$ (II)[H4] salen and [H2] salen complexes. Environ Prog Sustain Energy 2015, 34:1120-1128.

35. Li H, McDonald AG: Fractionation and characterization of industrial lignins. Ind Crop Prod 2014, 62:67-76.

36. Mainka H, Hilfert L, Busse S, Edelmann F, Haak E, Herrmann AS: Characterization of the major reactions during conversion of lignin to carbon fiber. J Mater Res Technol 2015: In press.

37. Kim J-Y, Lee JH, Park J, Kim JK, An D, Song IK, Choi JW: Catalytic pyrolysis of lignin over HZSM-5 catalysts: Effect of various parameters on the production of aromatic hydrocarbon. J Anal Appl Pyrolysis 2015, 114:273-280. 
38. Yang S, Zhang Y, Yuan TQ, Sun RC: Lignin-phenol-formaldehyde resin adhesives prepared with biorefinery technical lignins. J Appl Polym Sci 2015, 132:1-8.

39. Yu Z, Gwak KS, Treasure T, Jameel H, Chang Hm, Park S: Effect of lignin chemistry on the enzymatic hydrolysis of woody biomass. ChemSusChem 2014, 7:1942-1950.

40. Cabrera E, Muñoz MJ, Martín R, Caro I, Curbelo C, Díaz AB: Comparison of industrially viable pretreatments to enhance soybean straw biodegradability. Bioresour Technol 2015, 194:1-6.

41. Yang F, Afzal W, Cheng K, Liu N, Pauly M, Bell AT, Liu Z, Prausnitz JM: Nitric-acid hydrolysis of Miscanthus giganteus to sugars fermented to bioethanol. Biotechnol Bioprocess Eng 2015, 20:304-314.

42. Lacerda TM, Zambon MD, Frollini E: Oxalic acid as a catalyst for the hydrolysis of sisal pulp. Ind Crop Prod 2015, 71:163-172.

43. Jung YH, Park HM, Kim KH: Whole slurry saccharification and fermentation of maleic acid-pretreated rice straw for ethanol production. Bioprocess Biosyst Eng 2015, 38:1639-1644.

44. Yokoyama T: Revisiting the Mechanism of $\beta-0-4$ Bond Cleavage During Acidolysis of Lignin. Part 6: A Review. J Wood Chem Technol 2014, 35:27-42.

Novel model lignin compounds were used to reinvestigate the acidolysis of lignin's $\beta$-0-4' alkyl-aryl ether bonds. An unknown chemical mechanism was discovered using $\mathrm{HBr}$ and lignin, which differed from mechanisms seen with $\mathrm{HCl}$ and $\mathrm{H}_{2} \mathrm{SO}_{4}$.

45. Mitchell VD, Taylor CM, Bauer S: Comprehensive analysis of monomeric phenolics in dilute acid plant hydrolysates. BioEnergy Res 2014, 7:654-669.

46. Ko JK, Kim Y, Ximenes E, Ladisch MR: Effect of liquid hot water pretreatment severity on properties of hardwood lignin and enzymatic hydrolysis of cellulose. Biotechnol Bioeng 2015, 112:252-262.

47. Han Q, Jin Y, Jameel H, Chang H-m, Phillips R, Park S: Autohydrolysis Pretreatment of Waste Wheat Straw for Cellulosic Ethanol Production in a Co-located Straw Pulp Mill. Appl Biochem Biotechnol 2015, 175:1193-1210.

48•. Zhu M-Q, Wen J-L, Su Y-Q, Wei Q, Sun R-C: Effect of structural changes of lignin during the autohydrolysis and organosolv pretreatment on Eucommia ulmoides Oliver for an effective enzymatic hydrolysis. Bioresour Technol 2015, 185:378-385.

At lab-scale, the authors successfully generated three valuable fractions using biorefinery processes. Uniform molecular weight lignin, highly digestable carbohydrates, and solubilized xylooligomers from hemicellulose were all generated as valuable products with good yields.

49. Rana D, Laskar D, Srinivas K, Ahring B: Wet explosion pretreatment of loblolly pine leads to an increase in methoxylation of the lignin. Bioresour Bioprocess 2015, 2:1-10.

The investigated pretreatment modified the lignin structure with evidence of increasing syringyl moieties and the loss of hydroxyphenyl moities in the pretreated lignin compared to its raw state- a phenomenom not previously observed. A mechanism for in situ methoxylation is proposed.

50. Antonopoulou G, Gavala HN, Skiadas IV, Lyberatos G: The Effect of Aqueous Ammonia Soaking Pretreatment on Methane Generation Using Different Lignocellulosic Biomasses. Waste and Biomass Valorization 2015, 6:281-291.

51. Shimizu S, Posoknistakul P, Yokoyama T, Matsumoto Y: Quantitative difference in the rates of the $\beta-0-4$ bond cleavage between lignin model compounds with and without $\gamma$-hydroxymethyl groups during the alkaline pulping process. BioResources 2013, 8:4312-4322.

52- Karp E, Resch MG, Donohoe BS, Ciesielski PN, O'Brien MH, Nill JE, Mittal A, Biddy M, Beckham GT: Alkaline pretreatment of switchgrass. ACS Sustain Chem Eng 2015, 3:1479-1491.

The authors demonstrate the trade-off between carbohydrate recovery and lignin removal using alkaline pretreatment. It was found that delignification of nonwoods using sodium hydroxide depended on the alkali charge.

53. Humpula JF, Uppugundla N, Vismeh R, Sousa L, Chundawat SPS, Jones AD, Balan V, Dale BE, Cheh AM: Probing the nature of AFEX-pretreated corn stover derived decomposition products that inhibit cellulase activity. Bioresour Technol 2014, 152:38-45. 
54. Lehto J, Pakkanen H, Alén R: Characterization of Lignin Dissolved During Alkaline Pretreatment of Softwood and Hardwood. J Wood Chem Technol 2015, 35:337-347.

55. Xu J-K, Sun Y-C, Sun R-C: Synergistic effects of ionic liquid plus alkaline pretreatments on eucalyptus: Lignin structure and cellulose hydrolysis. Process Biochem 2015, 50:955-965.

56. Imman S, Arnthong J, Burapatana V, Champreda V, Laosiripojana N: Influence of alkaline catalyst addition on compressed liquid hot water pretreatment of rice straw. Chem Eng J 2014, 278:85-91.

57. Li J, Gellerstedt G: Improved lignin properties and reactivity by modifications in the autohydrolysis process of aspen wood. Ind Crop Prod 2008, 27:175-181.

58. Toledano A, Erdocia X, Serrano L, Labidi J: Influence of extraction treatment on olive tree (Olea europaea) pruning lignin structure. Environ Prog Sustain Energy 2013, 32:1187-1194.

59. Romero I, López-Linares JC, Delgado Y, Cara C, Castro E: Ethanol production from rape straw by a twostage pretreatment under mild conditions. Bioprocess Biosyst Eng 2015, 38:1469-1478.

60. Hendrianie N, Juliastuti SR, Iwani MI, Eka A: Lignocellulosic Processing with Acid Pretreatment and Enzymatic Hydrolysis for Improving the Acquisition of Sugar Fermentation. Mod Appl Sci 2015, 9:2328.

61. Samuel R, Pu Y, Raman B, Ragauskas AJ: Structural characterization and comparison of switchgrass ballmilled lignin before and after dilute acid pretreatment. Appl Biochem Biotechnol 2010, 162:62-74.

62. Wang K, Yang H, Yao X, Xu F, Sun R-c: Structural transformation of hemicelluloses and lignin from triploid poplar during acid-pretreatment based biorefinery process. Bioresour Technol 2012, 116:99-106.

63. Kaparaju P, Felby C: Characterization of lignin during oxidative and hydrothermal pre-treatment processes of wheat straw and corn stover. Bioresour Technol 2010, 101:3175-3181.

64. Li J, Henriksson G, Gellerstedt G: Lignin depolymerization/repolymerization and its critical role for delignification of aspen wood by steam explosion. Bioresour Technol 2007, 98:3061-3068.

65. Zeng J, Tong Z, Wang L, Zhu J, Ingram L: Isolation and structural characterization of sugarcane bagasse lignin after dilute phosphoric acid plus steam explosion pretreatment and its effect on cellulose hydrolysis. Bioresour Technol 2014, 154:274-281.

66. Sun S-N, Li H-Y, Cao X-F, Xu F, Sun R-C: Structural variation of eucalyptus lignin in a combination of hydrothermal and alkali treatments. Bioresour Technol 2015, 176:296-299.

67. Bozell JJ, Astner A, Baker D, Biannic B, Cedeno D, Elder T, Hosseinaei O, Delbeck L, Kim J-W, O'Lenick C: Integrating Separation and Conversion-Conversion of Biorefinery Process Streams to Biobased Chemicals and Fuels. BioEnergy Res 2014, 7:856-866.

68. Bozell JJ, O'Lenick C, Warwick S: Biomass fractionation for the biorefinery: Heteronuclear multiple quantum coherence-Nuclear magnetic resonance investigation of lignin isolated from solvent fractionation of switchgrass. J Agric Food Chem 2011, 59:9232-9242.

69. Hu G, Cateto C, Pu Y, Samuel R, Ragauskas AJ: Structural characterization of switchgrass lignin after ethanol organosolv pretreatment. Energy Fuels 2011, 26:740-745.

70. Gu F, Wang W, Jing L, Jin Y: Effects of green liquor pretreatment on the chemical composition and enzymatic digestibility of rice straw. Bioresour Technol 2013, 149:375-382.

71. Hussin MH, Rahim AA, Ibrahim MNM, Brosse N: Physicochemical characterization of alkaline and ethanol organosolv lignins from oil palm (Elaeis guineensis) fronds as phenol substitutes for green material applications. Ind Crop Prod 2013, 49:23-32.

72. de Carvalho DM, Sevastyanova O, Penna LS, da Silva BP, Lindström ME, Colodette JL: Assessment of chemical transformations in eucalyptus, sugarcane bagasse and straw during hydrothermal, dilute acid, and alkaline pretreatments. Ind Crop Prod 2015, 73:118-126.

73. Yuan T-Q, You T-T, Wang W, Xu F, Sun R-C: Synergistic benefits of ionic liquid and alkaline pretreatments of poplar wood. Part 2: Characterization of lignin and hemicelluloses. Bioresour Technol 2013, 136:345-350.

74. Wen J-L, Sun S-L, Xue B-L, Sun R-C: Quantitative structures and thermal properties of birch lignins after ionic liquid pretreatment. J Agric Food Chem 2013, 61:635-645. 


\section{Graphical Abstract}

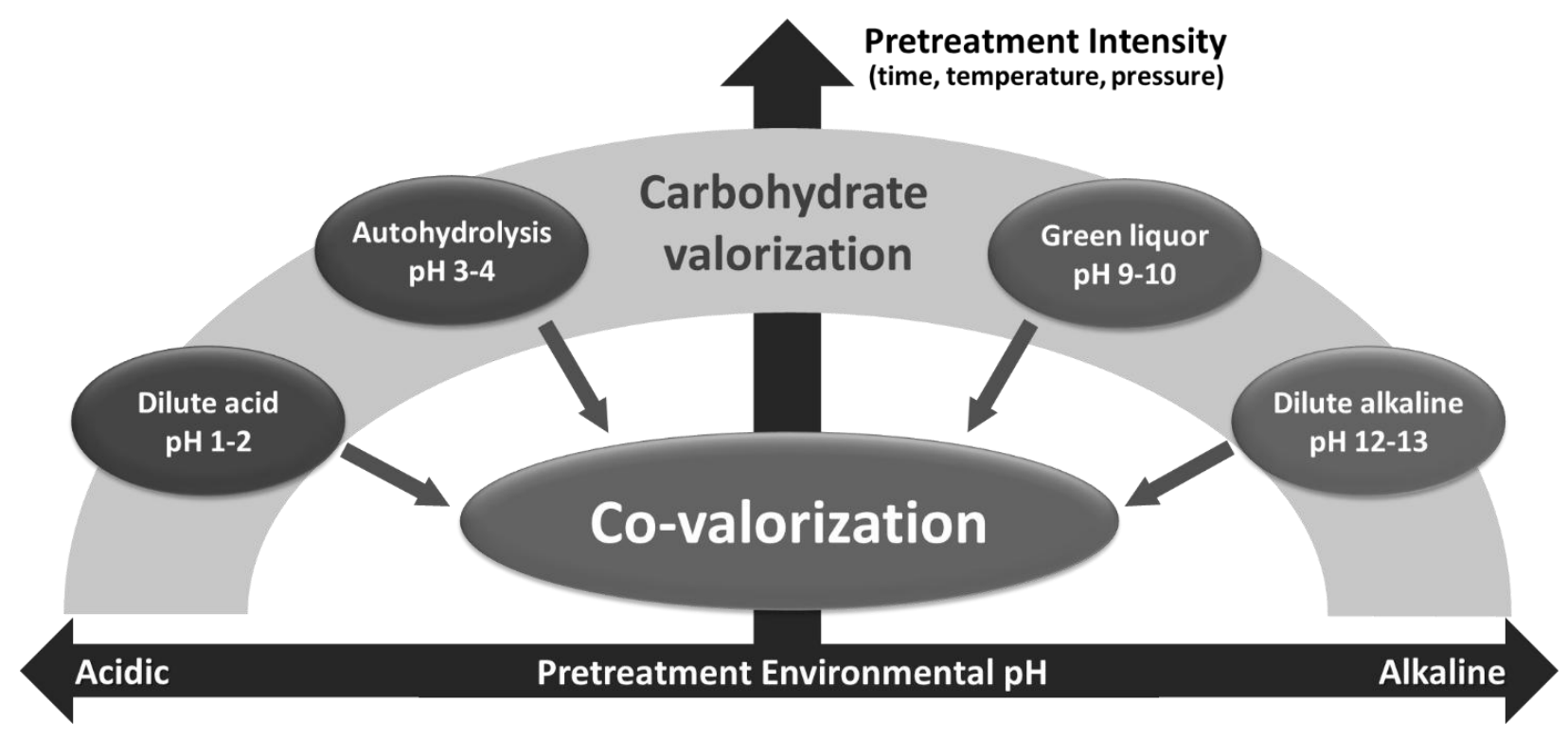

